\title{
The problem of Turkestan colonialism in Soviet historiography
}

\author{
Axmedov Gulmamat Nurmamatovich ${ }^{1}$ \\ ${ }^{1}$ Researcher of Samarkand State Museum-Reserve, Uzbekistan \\ Email:_axmedov_g@umail.uz
}

\begin{abstract}
The role and opportunities of historiography in educating the future generation of independent Uzbekistan, in forming in their minds the idea of national independence and patriotism are limitless. Without a historical past, no nation has a present and no future. The science of historiography makes people think, distinguishing historical events helps to analyze and draw practical and vital conclusions from them.
\end{abstract}

Keywords: historiography, Turkestan, Kokand.

\section{INTRODUCTION}

In the historiography of the period studied in the early twentieth century, the general politicization of the science, the tendency to "expose" and label, to accuse the "Pokrovsky school" of manuscripts, Trotskyism, bourgeois nationalism. According to the students of the Center and the Central Committee of the CPSU (b), the Central Asian Bureau's resolution of May 23, 1934, recommended in Central Asian historiography "the abolition of the concept of bourgeois-colonialism," which is clearly controversial in content and quality. It leads to the emergence of existing jobs. ${ }^{1}$ Analyzing the situation at that time, M. Chokaev wrote that "Turkistan is under Soviet rule. On the Characteristics of the Dictatorship of the Proletariat, "the foreword reads: ${ }^{2}$

He was instructed to study the problem of "annexation of non-Russian peoples to Russia" in connection with the choice of the path of politicization of history, as well as its growing dependence on the dictatorial regime. As a result, in history, the concept of "addition is absolute ignorance" has been replaced by a new approach of "addition is partial ignorance." ${ }^{3}$

\section{MATERIALS AND METHODS}

Historians dealing with the problems of colonialism have almost rejected the term 'occupation' and have rarely used the term 'invasion', instead replacing it with 'entry', 'introduction', 'annexation', 'o'. Terms such as "optional addition" began to be used. As a result, the negative consequences of the colonial regime, the reduction of the importance of the struggle of the indigenous people for freedom against the regime, the attempt to block its national liberation, and other similar measures were taken. In particular, the "Autonomous Government" formed in Kokand was described as counter-revolutionary, "bourgeois-nationalist", "panIslamic", and national organizations formed in Turkestan after the February Revolution as anti-people and absolute reactionary.

\section{DISCUSSION}

Nevertheless, by the first half of the 1960s and 1980s, the problematic scope of research expanded, and the accumulated experience and specific reality set the task of studying many aspects of the socio-economic, political and cultural life of the Turkestan peoples. resolved in a number of studies. ${ }^{4}$

${ }^{1}$ Galuzo P.G. Trotskyist-colonialist conception of the history of Russian domination in Central Asia. Revolution in Central Asia. Sat 3. T., 1932; Gurevich A. On the situation on the historical front of Central Asia. Revolution and culture in Central Asia. Sat 1. T., 1934.

${ }^{2}$ Mustafa Chokaev. Turkestan under the rule of the Soviets. Oxford, 1986.11-16.

${ }^{3}$ To the study of history. Sat. articles. M., 1937; A. V. Yakunin On the application of the concept of "the least evil" in assessing the annexation of non-Russian nationalities to Russia. "Questions of history". 1951, \# 11; M.V. Nechkin. On the question of the "least evil" formula. "Questions of history". 1951. No. 4;

Materials of the joint scientific session dedicated to the history of Central Asia and Kazakhstan in the preOctober period. T., 1955.

${ }^{4}$ Aminov A. Economic development of Central Asia (from the second half of the 19th century to the First World War). T., 1959; F.A. Azadaev Tashkent in the second half of the 19th century Essays on socio-economic and political history. T., 1965; Ziyaev Kh.Z. Central Asia and the Volga region (second half (XVI-XIX centuries). T., 1965; Tukhtametov T. G. Russian-Bukhara relations at the end of the XIX-beginning. XX centuries T., 1966; Sadykov A.S. Economic relations Khiva with Russia in the second half of the 19th - 
Some aspects of the Turkestan people's way of governing during the colonial period can be seen in the revolutionary movements of Turkestan in 1905-1907 and 1917, as well as in the national liberation movements of the second half of the 19th and early 20th centuries.

Some aspects of Tsarist policy in Central Asia N.S. Kinyapina, M.M. Bliev, V.V. This is reflected in Degoev's research. In their research, they focused on issues such as the methods and principles of the administrative policy of the ruling class in Central Asia, the content of its work, plans, and general directions of the policy of the dictatorial tsarist government. While drawing the image of the Russian government's dominance in the Caucasus and Central Asia, the authors were forced to take into account the international aspects of administrative and political reforms in these regions (e.g., Anglo-Russian competition for dominance in Central Asia). they argue that the administrative-territorial policy was built in such a way that it should have served to increase Russia's prestige in both Central Asia and Europe.

Beginning in the second half of the 1980s, the principle of 'working with instructions' began to recede in scientific research in connection with 'reconstruction', and was replaced by historical principles. As a result, a number of national and international scientific conferences, symposiums and meetings have been held. ${ }^{5}$ they discussed topical issues of historical science. In particular, many issues related to the recent and recent history of the Uzbek people have been reviewed, thought out, re-analyzed, and insufficiently studied issues, including the issue of Tsarist Russia's occupation of Central Asia, the history of statehood, the study of the nature and features of the colonial and Soviet power management systems, the emphasis on identifying their specific features.

\section{RESULT}

The real possibilities of creating scientific works in a qualitatively new conceptual way, based on generally accepted scientific principles and the ideology of national independence, appeared in the 90s. As a result, a number of scientific works, newspapers, pamphlets and articles written in the spirit of independence were published, and scientific research was conducted. In these works, the history of the colonial policy of tsarism, Jadidism, the history of political parties that emerged after the February Revolution of 1917, a new interpretation of the history of the national liberation movement were considered. The topic of statehood is reflected in a number of articles, $\mathrm{PhD}$ and doctoral dissertations.

Thus, a much wider range of problems: the structure, functions, peculiarities and features of the colonial system of government, the basic principles of military rule in Turkestan; emergence, activities, goals and objectives of national-political organizations; The main aspects and features of national issues in the political history of Turkestan 6 ; leading trends in the socio-economic and socio-political life of Turkestan after the overthrow of tsarism; development of the reform movement in the country, its emergence, stages, strategy and tactics; establishment of the Turkestan Autonomy, the first experience of national-democratic statehood; the defeat of the autonomy movement, its causes and the establishment of the Soviet model of autonomy; the attack of the Soviet government on the traditions of national statehood and other issues were studied.

\section{CONCLUSION}

In general, the analysis of the literature on the problem shows that despite the fact that Tsarist Russia introduced some aspects of the problem of colonial statehood and its development trends in Turkestan, the accumulated knowledge and results are significant, the Central Asian colonial state the dynamics and trends of improvement at historical stages require serious rethinking and extensive retrospective analysis.

\section{REFERENCES}

1. Aminov A. Economic development of Central Asia (from the second half of the 19th century to the First World War). T., 1959;

2. F.A. Azadaev Tashkent in the second half of the 19th century Essays on socio-economic and political history. T., 1965;

3. Ziyaev Kh.Z. Central Asia and the Volga region (second half (XVI-XIX centuries). T., 1965;

4. Tukhtametov T.G. Russian-Bukhara relations in the late XIX - early. XX centuries. T., 1966;

beginning of the 20th centuries T., 1965; Yuldashev A.M.Agrarian relations in Turkestan (late XIX - early XX). T., 1969; Khidoyatov G.A. From the history of the Anglo- Russian relations in Central Asia at the end of the 19th century.T., 1969; Khalfin N.A.Russia and the Khanates of Central Asia.Moscow, 1974.

${ }^{5}$ Interregional meeting on the problems of national liberation movements in Central Asia and Kazakhstan. T., December 23, 1987; History and historiography of national liberation movements in the second half of the XIX - early. XX centuries. in Central Asia and Kazakhstan. T., Fan, 1989; Military expansion and colonial policy of tsarism in Central Asia. T., May 1990. 
5. Sadykov A.S. Economic ties of Khiva with Russia in the second half of the XIX - early. XX centuries. T., 1965;

6. Yuldashev A.M. Agrarian relations in Turkestan (late XIX - early XX). T., 1969;

7. Khidoyatov G.A. From the history of Anglo-Russian relations in Central Asia at the end of the 19th century. T., 1969;

8. Khalfin N.A. Russia and the Khanates of Central Asia. M., 1974.

9. Ziyaev Kh.Z. National Liberation Movement 1916. "Social Sciences in Uzbekistan". 1991, no. 7;

10. Abdullaev R.M. From the history of the national movement in Turkestan after February Sadykov Kh.D. Colonial policy of tsarism in Turkestan and the struggle for independence at the beginning of the 20th century. Abstract. dis ... doct. historical sciences. -T., 1994;

11. Akhmedzhanov G.A. Russian Empire in Central Asia (History and Historiography of the Colonial Policy of Tsarism in Turkestan). T., 1995;

12. Alimova D.A. Historical worldview of the Jadids and their projection of the future of Turkestan, From the pages of the struggle for independence and unity of Turkestan. T., Science, 1996, pages 620;

13. Collection: New thoughts on the life and work of Fayzulla Khodjaev. T., Fan, 1997;

14. Iskhakov F. National policy of tsarism in Turkestan (1867-1917). T., Fan, 1997;

15. Abdullaev R.M. National-political organizations of Turkestan in 1917-1918 Abstract. dis ... doct. historical sciences. -T., 1998;

16. Ziyoev H.Z. Struggle against Russian aggression and domination in Turkestan (XVIII-XX a.b.). T., 1998;

17. New history of Uzbekistan. The first book. Turkestan during the colonial period of Tsarist Russia. T., «Sharq», 2000;

18. The second book. Uzbekistan during the Soviet colonial period. T., «Sharq», 2000;

19. Turkestan at the beginning of the 20th century: on the history of the origins of national independence. T., "Shark", 2000.

20. Abdurakhimova N.A. Colonial system of power in Turkestan (second half of XIX - early XX century). Abstract. dis ... doct. historical sciences. -T., 1994;

21. Tilavov A.T. Formation and development of the Soviet political system (1917-1924) Abstract. dis ... doct. historical sciences. -T., 1992; 